\title{
Cross-cultural Analysis of Al- Sadat's and Bush's First Inaugural Speeches
}

\author{
Imad Hayif \\ Department of English University of Anbar / Iraq \\ Dr. Ishraga Bashir \\ English Department Faculty of Arts Al-Neelain University Khartoum, Sudan
}

\begin{abstract}
The present cross-cultural investigation analyzes critically two culturally different inaugural speeches. The researchers have chosen the inaugural speech of the president Bush the son and the inaugural speech of the Syrian president Alasad. It explores the discursive practices of a presumably powerful leaders in two nations/cultures. Drawing upon the theoretical stance of CDA and intercultural pragmatics Theory, the study attempts to examine the contextually-controlled production of the inaugural discourses in the two cultures and the discursive decisions guided by the experts' context models, being the cognitive interface between discourse and society. The study combines analytic tools from socio-cognitive theory and CDA, in examining (i) the selection of topics and the discursive construction of contextual features, namely setting, participant's' identities, ideology, purposes and (ii) the strategic maneuverings performed revealing of the arguers' attempt to maintain balance between the dialectical and the rhetorical goals. The findings from the socio-cognitive study show that the patterns in the discursive practices of each speech indicate ideologically and culturally biased strategies, though they have common points.
\end{abstract}

Keywords: Cross Cultural, Pragmatics, Inaugural Speech and CDA theory

\section{INTRODUCTION}

Many factors contribute to change or modify the meaning of any text; therefore many sciences are combined to generate the final version of discourse. Culture is one element which affects the meaning of text. The researches define intercultural pragmatics as a relatively new field of inquiry which focuses on how the language system is put to use in social encounter between human beings who have different first languages, communicate in a common language and, usually represent different cultures. The conflict between culture, language and thought is tackled to show which one of these elements generates the others. The interpretation of these two speeches is affected by cognitive theory of Van Dijk who presents what is called' context model'. This model deals with abstract knowledge stored in human's mind about specific situations and topics. The definition of inaugural speech is discussed to present the common themes and characteristics of this genre. Two inaugural speeches belong to two different cultures are analyzed to show that even though they belong different cultures but they carry the same themes and characteristics.

\section{Cross Cultural and Intercultural communication}

Gudykunst (2000:314) states that most of linguists regard "cross-cultural and intercultural " interchangeable. They are, nevertheless, different .Cross -cultural research deals with comparing behavior in two or more cultures while intercultural research involves examining behavior when members belonging to two or more cultures interact with each other .As a 
result, understanding cross-cultural differences in behavior is a prerequisite for understanding intercultural behavior and the reverse is also true .This distinction raises a more fundamental issues: what is the distinction between intercultural communication and intracultural one?. The answer is that: The boundaries between the two cannot be clearly drawn.

Schutz (1972:53-69) guides us to the fact that every type of communication must include experiences of various individuals coincide only partially, and each person has something new and different .Although understanding operates depending on the principle of reciprocity of perspectives; that does not mean that it actually occurs .Understanding is not dependent on complete reciprocity; it is sufficient that a shared meaning can be developed . He (ibid:12) states that our idealizations of homogeneity are different. They depend on whom we find ourselves in contact with, in what manner. Tradition of interactional sociolinguistics has clarified that very subtle refinements of orientation to one another in conversation determine whether people will experience and define themselves as belonging more to an 'in-group 'or as belonging more to an ' out-group' . If the subtle interactional orientation to one another in the area covering all aspects of non-verbal communication does not succeed, we are prone to experience someone else.

According to Helga Kotthoff and Helen Spencer Oatey (2007 :2) People regard themselves as belonging to different social groups, and that group members, through contact and socialization process, develop family resemblances, which individual members acquire to greater or lesser extents in relation to different aspects, do not simplistically determine their behavior ; on the contrary, people through interaction which is a dynamic process, construct ( consciously or unconsciously ) their complex and multiple identities. The field of intercultural communication focuses on the study of this dynamic process. There is no need to say that intercultural communication can proceed very smoothly and successfully .On contrast, intracultural communication can be fraught with many difficulties. Moreover, not every misunderstanding in intercultural encounters is caused by cultural backgrounds, sometimes social conflicts can be culturized in that the notion of culture is used as an excuse to mask political or economic conflicts. For example, in many western countries, children who have migration backgrounds are low achievers at school and this not because of cultural problems but they need more training programs.

\section{Intercultural Pragmatics}

Kecskes (2011:371-87) states that intercultural pragmatics is a relatively new field of inquiry. Its focus is on how the language system is put to use in social encounter between human beings who have different first languages, communicate in a common language and ,usually represent different cultures .The communicative process followed in these encounters is synergistic in the sense that it is the merger in which the pragmatic norms of each participant are represented in some extent .Intercultural pragmatics reflects a sociocognitive perspective that includes individual prior experience and actual situational experience with an equal importance in meaning construction and comprehension . To understand intercultural pragmatics four main foci must be tackled which are: (1) interaction between native speakers and non-native speakers of a language; (2) lingua franca communication in which none of the interlocutors has the same first language; (3) multilingual discourse; and (4) language use and development of individuals who speak more than one language.

Kasper (1998:183 -208) mentions three aspects of pragmatics which must be clarified and distinguished to understand what is meant by cross cultural which are: interlanguage 
pragmatics, cross cultural pragmatic and intercultural pragmatics . Although these three aspects are often used interchangeably, they do not refer to the same inquiry.

The focus of interlanguage pragmatics is on the acquisition and use of pragmatic norms in a second language .It investigates the ways by which learners learn how to produce and comprehend speech acts and how their pragmatics competence develops over time. According to Boxer (2002:151), interlanguage pragmatics studies the language appropriation and acquisition of pragmatic norms represented in the host language community .

Boxer (ibid) argues that cross - cultural pragmatics takes the view that individuals from two societies or communities carry out their interaction ( whether spoken or written ) according to their own rules and norms accompanied with a clash of expectation and misperception about the other group. Kasper $(1996: 103-20)$ states that cross -cultural pragmatics deals with realization of speech act in different culture, pragmatic failure, cultural breakdowns, and how some linguistic behaviors are polite in one language and impolite in another one. A comparative approach to different cultural norms reflect in language use is followed to understand it easily. Interlanguage pragmatics and cross-cultural pragmatics study three theoretical constructs: Gricean pragmatics, Brown and Levinson's politeness theory and interchange hypothesis. The ability to comprehend and produce a communicative act is referred to as pragmatic competence. This concept usually investigates speaker's social status, the awareness of social distance, linguistic knowledge and cultural knowledge of both the explicit and implicit kind .

Kecskes (2005)as quoted in( Jackson, 2012:68) states that intercultural pragmatics differs significantly from interlanguage and cross -cultural pragmatics in its concerns .Differences are based on two factors : the sociocognitive approach and the understanding of interculturality .He also states that interlanguage pragmatics represents a monolingual while cross- cultural multilingual.

\section{Political Discourse}

According to Fairclough and Fairclough (2012:19), the jargon of vocabulary of political discourse is different from other types of discourse .It is a form of practical argumentation involving choices made as a respond to circumstances and goals.

Chilton (2004:23) discusses the relationship between cooperation and conflict in politics. He argues that politics is a struggle for power and in this struggle there is a cooperation to resolve clashes of interest .He (ibid) states, "political speakers have to guard against the operation of their audiences "cheater detectors" and have to provide guarantees for the truth of their sayings".

Wadak (2009:1) argues that politics requires imposing representation that serve power. She states." politics is intrinsically linked with shaping, thinking and doing". Her approach is known as the Discourse Historical Approach (DHA) which focuses mainly to explain how power relationships are constituted by the use of language that has political implication.

Schaffner (1996: 201-204) states that political discourse is a sub-category of discourse in general. It can be based on two criteria: functional and thematic. It is a result of political and it is culturally and historically determined. It fulfills different functions due to different political activities. It is thematic because its topics are directly related to politics. 
Rousseau (2004) (as cited in the New Fontana Dictionary Modern Thought 1999:678) states that the language has a key role in the exchanging of values in social life and transforming power into right and obedience into duty. Language may create power or it becomes an area in which power is applied. He states," the strongest is never strong enough always to be master unless he transforms his power into right and obedience into duty".

Wareing (2004: 9) states that the affective function of language is concerned with who is allowed to say what to whom, which is "deeply tied up with power and social status".

Jones and Peccei (2004: 12) mention that politicians throughout the ages have achieved success depending on their skillful use of rhetoric by which they can persuade their audience that their views are valid.

\section{Inaugural Speech}

Presidential inaugural speeches are the most important political discourses. They are of great significance to the new president, because this is the very special moment when he stands before the whole nation or even the whole world to express his fundamental political policies and principles for the country's development during the period of his presidency. Depending totally on this kind of discourse, the president aims at convincing citizens, boosting their morale, motivating the confidence of people and seeking the largest amount of support from his citizens. To achieve this task, the president will carefully weigh his words in his speech, and polish it by resorting to different language skills and strategies. One of these strategies is a metaphor which appears to be adopted widely and also used effectively. According to Lakoff and Johnson (1980: 3), metaphors are pervasive in daily life, not just in language but also in thought and action. They means that people may sometimes depend on conceptualizing a particular concept in terms of another to enabling them understand some abstract concepts much easier and clearer by adopting words that have concrete referents. Metaphor is a means to manifest or clarify the speech acts utilized by politicians.

According to Campbell and Jamieson(1992:14),the significant of presidential inaugural speech is recognized by all but few praise .Arthur Schlesinger , Jr ,for example ,acknowledge that ,during inaugural speeches "the nation listen for a moment as one people to the words of the man they have chosen for the highest office in the land ".but he find little merit in them :

Even in the field of political oratory, the inaugural address is Inferior art form .It is rarely an occasion for original thought or stimulating reflection. The platitude quotient tend to be high, The rhetoric stately and self- serving , the ritual obsessive , and the Surprises few.

They (ibid ) states that inaugural addresses are maligned because their symbolic function is misunderstood .They are essential element in the ritual of transition in which the covenant between the citizenry and their leaders is renewed .Ordinary language and conventional wisdom consider inaugural addresses as a class .Likewise critics consider them a distinct rhetorical type but generalizing about them is difficult. In spite of the fact that there are many apparent differences among them, the study will approach them a group. Presidential inaugurals are a subspecies of the kind of discourse that is called by Aristotle as epideictic .Epideictic is a form of rhetoric that praises or blames on ceremonial occasion ,invite the audience to evaluate the speaker ,speaker's performance ,recall the past and speculate about the future, while focusing on the present ,depending on dignified ,noble literary style ,and rehearses or amplifies admitted facts .

O'Malley as cited in Campbell and Jamieson (ibid: 15) comments that ' epideictic wants as far as possible to present us with works and deeds, ... not for metaphysical analysis but quite literary for viewing ... 'to look' ,'to view ','to gaze' upon and to ' contemplate ' 
Harry Caplan as quoted in Campbell and Jamieson (ibid) states that epideictic discourse motivates the speaker to impress his ideas upon the audience without action as a goal. If these characteristics are found, presidential inaugurals are epideictic rhetoric because they are delivered on ceremonial occasions, link or connect past with future in present contemplation ,affirm or praise the shared principles that have a significant role in guiding the incoming administration, ask the audience to 'gaze upon ' traditional values, employ or use elegant ,literary language relying on the heightening of the effect by amplification and reaffirmation of what is already known and believed.

The general qualities of epideictic rhetoric modified by the nature of presidential investiture generate five interrelated elements that define the essential presidential inaugural address and differentiated it from other types of epideictic rhetoric:

1-Unify the audience.

2-Rehearse communal values draw from the past.

3- Set forth political principles of the new administration.

4-Enact the requirements and limitations of the office.

5-Use appropriate epideictic address strategies.

The first four characteristics are the motives or goals of inaugural address while the last one provides insight into the stylistic means used to achieve their ends.

Ericson (1997:727), investigates and analyzes 52 presidential inaugural addresses, states that most inaugurals include the following themes: civic virtue , nonpartisanship ,national unity, general policy principles ,cooperating with congress ,seeking popular support ,supreme being , The American mission and political continuity. Many themes are sometimes related to multiple characteristics .For example: themes related to "unifying the audience" include nonpartisanship and national unity.

\section{CRITICAL DISCOURSE ANALYSIS (CDA)}

Critical discourse analysts focus on relationship between discourse, power, dominance and social inequality and how discourse reproduces and maintains these relations of dominance and inequality. Van Dijk (1993: 249) states that because of analysts' concern with the analysis of the often opaque relationships between discourse practices and wider social and cultural structures, CDA practitioners take an explicit socio- political stance (ibid: 252).

Fairclough (2001:26) defines CDA saying that it is concerned with the analysis of text and interactions but it does not start from texts and interactions .Problems which face people in their social lives and issues which are taken up with sociology, political science and/or cultural studies form the starting point and the milestone of this science.

CDA researchers concern in studying how the microstructures of language are linked with and help to shape the macrostructures of society .CDA maintains that discourse (the use of language in speech and writing) should be regarded as a social practice. Fairclough (1992:10) states that every instance of language use has three dimensions: it is a spoken or written language text; it is an interaction between people involving processes of producing and interpreting the text; and it is a piece of social practice. This view of discourse implies dealing with issues such as institutional circumstance of the discursive event and how that forms or shapes the nature of the discursive practices and the constitutive effects of discourse. 


\section{METHODS OF ANALYSIS}

The most important and comprehensive views and ideas in Critical Discourse Analysis are Van Dijk' views. He proposes a sociocognitive approach to analyze the (re)production of social features in a text. Van Dijk suggests a multidisciplinary Approach within CDS that explicitly studies the structures of a text. It analyzes social and cognitive contexts of a text (van Dijk 2006: 161). Crucial to this approach is the relationship between discourse, cognition and society. Discursive construction of context in the sociocognitive approach Dijk states that, social cognition and personal cognition together constitute a discourse that socially oriented, in other words, it is a kind of mediation between society and discourse. He defines social cognition as "the system of mental representations and processes of group members" (ibid:18).He considers "ideologies as the overall, abstract mental systems that are organized socially. Ideologies, thus , "indirectly influence the personal cognition of group members" in their act of comprehension of discourse among other actions and interactions (ibid.19). He calls the mental representations of individuals during such social actions and interactions "models". For him, "models control how people act, speak or write, or how they understand the social practices of others" (ibid. 2). Of crucial importance here is that, according to Dijk, mental representations are often used by the speakers to present themselves or their own group in positive terms, and other groups in negative terms. The case of inaugural speeches, it is" I" against you, I am the one who has all the positive quality to lead you (ibid: 22).The characteristic proposed by Ericson are studied to prove that the content of this genre of speech is similar in the Arabic and American culture.

\section{DATA ANALYSIS}

Two presidential inaugural speeches are chosen randomly to find out whether they are different or similar in what they reflect or content. The first one is that of al Sadat while the second one is of Bush who is distinguished by his aggressive personality.

\section{Al -Sadat First Inaugural Speech}

Medium has its role in this kind of speech because it determines the credibility and reliability of the speech. The audio- visual characteristics of this speech are not available because it is found as written copy but it is clear from the content of the speech that the new president beseeches the people to accept him as a president. He repeats the sentence which states that many Egyptians reject him as president many times. The time in which El Sadat is nominated as president is critical because he came after the period of the strongest leader. Most Egyptians adore Jamal Abdul Nasser and they think that no one can replace him. This thought forms impediment in the way of new president. Al Sadat repeats the sentences that talk about the difficulty of task many times and mentions the achievements of Abdul Nasser many times to convince Egyptians that he will replace him and be a good president.

Audience's opinions, emotions and attitude have their role in determining the credibility or reliability of event models being conveyed. What is important here is that Al Sadat's words imply that he will imitate and follow Abdul Nasser policy resorting to the positive ingroup information to convince the listeners accept his ideas and opinions.

He overuses the use of the pronoun ' we ' and mention the results of the elections to say that he talks to them as an elected president. Talking about the themes that form the corner stone of this kind of speech which are civic virtue, nonpartisanship, national unity, general policy principles, cooperating with Government, seeking popular support, calling upon a supreme being, the Egyptian's mission and political continuity is also an important factor in this genre. These themes are found in many effective inaugural speeches are proposed by Campbell and 
Jamieson and dissolved within the five key characteristics proposed by Ericson. These characteristics are:

(a) unifying the audience

(b) rehearse communal values draw from the past

(c) set fourth political principles of the new administration

(d) enact the requirements and limitation of the office

(e) use appropriate epideictic strategies

\section{Unifying the audience}

This theme forms the basic factor from which the speaker can launch to draw audience' attention and achieve most of his objectives. This theme always gives priority to personal pronouns, especially the pronoun ' we' as clarified in the following sentence. The president replaces the pronoun 'we' by resorting to combining two pronouns which are 'you' and 'me' when he says," You will all be with me along the road"

You will all be with me along the road which extends towards the horizon of our cherished hope.

\section{Rehearse Communal Values Drawn from the Past}

Mentioning what the nation has in common supports the speaker to a higher extent, therefore, Almighty God and the previous immemorable leader are mentioned a lot.

I have received your directive, and I pray to Almighty God that I will perform the task which you have entrusted to me in a manner satisfactory to our people and nation and compatible with the ideal laid down by the immemorable leader and for which he gave everything, from live to death.

It was the will of God Almighty - and there can be no objection to his will or wisdom - to test our steadfastness, with what we cherished most and with the dearest thing we possessed at one of the most critical circumstances.

\section{Set Forth Political Principle of the New Administration}

This genre cannot realize its basic objective without the commitment of the speaker to do something distinguished in the future. This theme highlights the use of specific words especially two words which are ' promise and pledge'

I promise you that I shall stand for everyone; for those who said $<<$ yes $>>$ and those who said $<<$ no $>$. The homeland is for all and the responsible person in it is entrusted with every individual in it without exception.

\section{Enact the Requirements and Limitation of the Office}

As expected, the president did not mention anything concerning this characteristic because he did his best to convince the audience without mentioning any limitation which make him handcuffed person. 


\section{Use Epideictic Address strategies}

Epideictic means to achieve the four ends previously mentioned are seized in a good way by the speaker where he talks about the past and after that moves to indicate the present without forgetting to talk about the future.

\section{Bush's First Inaugural Speech}

The peculiar circumstances of Bush's election because he is the only the only third president to lose the popular vote and win the electoral count. He is offered an opportunity to explore the creation of presidential authority. He could hardly have been unaware of his plight. Protestors lined the streets chanting" Hail to the thief," and a poll released on inauguration eve revealed that only 51 percent of Americans, a bare majority, considered his election legitimate. This rate includes 19 percent of Democrats and 12 percent of African Americans. This rate motivate Bush to say," Sometimes our difference run so deep, it seems we share a continent but not a country." To make of himself a president, he would have to make of continent a country. The inaugural speech is a good start.

For more understanding, the medium is relevant; recipients may find that the audio-visual in inaugural speech is more credible and reliable than written one because non- verbal communicative devices play their role in this scope especially with the president (Bush) who seizes the prosodic features in a good way. The tone of his voice is exploited well. Besides the movement of Bush's eyes has its role in drawing audience attention. Camera work in the videos shows George Bush with a bigger close-up and we can only see his head and shoulders. During the Bush's speech, from time to time the camera shows the mob gathered in front of the United States Capitol in Washington, D.C, and some special guests, such as the First Lady Laura Bush or President Bill Clinton .Bush speaks quietly raising his voice a bit only a couple of times. He speaks slowly and, in my opinion, quite monotonous. He also delivers short pauses regularly. Bush sometimes looks at his notes.

The contextual time category is of course crucial for processing of this genre. Similar observations hold for the contextual category of location. The contextual categories of time and location are irrelevant in this kind of speech because they are stable and chosen in a good way to give worth value to this occasion. The circumstances category requires that the content of this kind of speech and its event would be relevant to ongoing social and political events. This means that the circumstances category regulates the urgency and priority of the inclusion of specific event model information in actual inaugural discourse meanings, the macrostructural hierarchy of semantic representations, as well as the prominent with which such meaning are expressed in the speech. The communicative of the speaker with associated structures of interest, experience, or ideologies, some information of the model may be focused on what is worth and what is found interesting for the audience.

Perhaps most crucial for transformation of event model into discourse meaning is the role of knowledge of the speaker and the audience. As suggested before, sociocultural knowledge and opinions that the speaker presupposes to be shared by the audience will not generally be fully expressed, but merely signaled.

Readers' opinions, emotions, altitude, and ideologies will be brought to bear in specific judgments both about the events and about the speaker, and hence about the credibility or reliability of event models being conveyed.

One major factor frequently found to facilitate and comprehend the speech is that of personal interest, an attribute that we define as motivation to acquire knowledge about specific topic. 
The general strategy here is that positive information about ingroup and negative information about outgroup will be included or highlighted, where negative information about the ingroup and positive information about outgroup will tend to be suppressed or downgraded.

What is important here is that Bush's words imply that he will make many future projects to serve American. In this kind of speech, the speaker resorts to positive ingroup information to persuade the audience accept his ideologies and opinions.

The social domain of this speech is media communication. Typical participants are American people and the speaker (the president). Typical genre is inaugural speech. Both in production and comprehension, this genre tells the participants that the event model expressed in this kind of speech is intended to guide, direct or draw the public policy of the country which implies, among other things, that most socioculturally known information may be left implicit. The implication is usually manifested through using indirect speech acts. The social function of inaugural speech regulates which information about an event is worthy and publicly relevant or interesting, and what information is not. Most specifically, contextual knowledge about the type of communicative event or genre (inaugural speech) tells the participants what specific communicative functions this genre has and the event model information is or should be most relevant to accomplish this function. More generally, genre information regulates the choice of specific topics and their hierarchical importance. These themes are civic virtue, nonpartisanship, national unity, general policy principles, cooperating with Congress, seeking popular support, calling upon a supreme being, the American mission and political continuity. The first four themes of Campbell and Jamieson represent the motives or goals of inaugural speech while the last one indicates the insight through which the stylistic means used to achieve these motives. These themes and characteristics cannot be found within specific order in this kind of speech. These themes are:

\section{Unifying the audience}

From the beginning, Bush talks about the peaceful transfer of authority because it is something exclusive to the American nation.

He uses the pronouns "We" and "Our" to achieve or reflect this characteristic. He says, "We recall that what binds this nation together is not the colors of our skin or the tenets of our faith or the origins of our names".

What makes us exceptional -- what makes us American -- is our allegiance to an idea articulated in a declaration made more than two centuries ago.

We made ourselves a new, and vowed to move forward together.

Now, more than ever, we must do these things together, as one nation and one people.

My fellow Americans, we are made for this moment, and we will seize it -- so long as we seize it together.

Today, we affirm a new commitment to live out our nation's promise through civility, courage, compassion and character.

The most important tasks of a democracy are done by everyone. 
An unfolding American promises that everyone belongs, that everyone deserves a chance, and that no insignificant person was ever born.

\section{Rehearse Communal Values Drawn from the Past}

"We hold these truths to be self-evident, that all men are created equal; that they are endowed by their Creator with certain unalienable rights; that among these are life, liberty, and the pursuit of happiness."

The patriots of 1776 did not fight to replace the tyranny of a king with the privileges of a few or the rule of a mob.

Through blood drawn by lash and blood drawn by sword, we learned that no union founded on the principles of liberty and equality could survive half-slave and half-free. A decade of war is now ending.

We are true to our creed when a little girl born into the bleakest poverty knows that she has the same chance to succeed as anybody else, because she is an American; she is free, and she is equal, not just in the eyes of God but also in our own.

For we remember the lessons of our past, when twilight years were spent in poverty and parents of a child with a disability had nowhere to turn.

We must act, knowing that today's victories will be only partial and that it will be up to those who stand here in four years and 40 years and 400 years hence to advance the timeless spirit once conferred to us in a spare Philadelphia hall.

My fellow Americans, the oath I have sworn before you today, like the one recited by others who serve in this Capitol, was an oath to God and country, not party or faction.

-God bless you all, and God bless America

-I know this is in our reach because we are guided by a power larger than ourselves who creates us equal in His image.

\section{Set Forth Political Principle of the New Administration}

Together, we determined that a modern economy requires railroads and highways to speed travel and commerce, schools and colleges to train our workers.

Together, we discovered that a free market only thrives when there are rules to ensure competition and fair play.

Never tiring, never yielding, never finishing, we renew that purpose today, to make our country more just and generous, to affirm the dignity of our lives and every life.

Together, we resolved that a great nation must care for the vulnerable, and protect its people from life's worst hazards and misfortune.

For we, the people, understand that our country cannot succeed when a shrinking few do very well and a growing many barely make it.

We believe that America's prosperity must rest upon the broad shoulders of a rising middle class. 
We, the people, still believe that every citizen deserves a basic measure of security and dignity. We must make the hard choices to reduce the cost of health care and the size of our deficit.

The commitments we make to each other through Medicare and Medicaid and Social Security, these things do not sap our initiative, they strengthen us.

So we must harness new ideas and technology to remake our government, revamp our tax code, reform our schools, and empower our citizens with the skills they need to work harder, learn more, reach higher.

We must make the hard choices to reduce the cost of health care and the size of our deficit.

We will respond to the threat of climate change, knowing that the failure to do so would betray our children and future generations.

For our journey is not complete until our wives, our mothers and daughters can earn a living equal to their efforts. Our journey is not complete until our gay brothers and sisters are treated like anyone else under the law - for if we are truly created equal, then surely the love we commit to one another must be equal as well. Our journey is not complete until no citizen is forced to wait for hours to exercise the right to vote. Our journey is not complete until we find a better way to welcome the striving, hopeful immigrants who still see America as a land of opportunity- until bright young students and engineers are enlisted in our workforce rather than expelled from our country. Our journey is not complete until all our children, from the streets of Detroit to the hills of Appalachia, to the quiet lanes of Newtown, know that they are cared for and cherished and always safe from harm.

That's how we will maintain our economic vitality and our national treasure - our forests and waterways, our crop lands and snow-capped peaks. That is how we will preserve our planet, commanded to our care by God.

\section{Enact the Requirements and Limitation of the Office}

For history tells us that while these truths may be self-evident, they've never been selfexecuting; that while freedom is a gift from God, it must be secured by His people here on Earth. They gave to us a republic, a government of, and by, and for the people, entrusting each generation to keep safe our founding creed.

Through it all, we have never relinquished our skepticism of central authority, nor have we succumbed to the fiction that all society's ills can be cured through government alone.

That preserving our individual freedoms ultimately requires collective action. For the American people can no more meet the demands of today's world by acting alone than American soldiers could have met the forces of fascism or communism with muskets and militias. No single person can train all the math and science teachers we'll need to equip our children for the future, or build the roads and networks and research labs that will bring new jobs and businesses to our shores.

I am honored and humbled to stand here, where so many of America's leaders have come before me, and so many will follow. 
I ask you to be citizens: citizens, not spectators; citizens, not subjects; responsible citizens, building communities of service and a nation of character.

\section{Use Epideictic Address strategies}

This characteristic implies the use of epideictic means to achieve the four ends previously mentioned. The epideictic speech is demonstrative in nature and frequently calls on the past or refers to the future to establish honor or dishonor in the present. There are three components which are necessary in a political epideictic. They are: urging contemplation, not action; focusing on the present while incorporating the past; and praising the institution of the presidency, common values, and the form of government .This speech meets these content requirements.

\section{CONCLUSION}

The data are chosen from two different cultures to answer a basic question about whether this genre of speech differs from one culture to another. The analysis shows that the two speeches have many common points. One of these points is the themes tackled in them. The presidents talk about the same topics; therefore the same ideologies are followed by them. Knowing the importance of this kind of speech, presidents resort to group of experts to achieve this task. The two samples are characterized by the overuse of personal pronouns such as 'we' and 'I' to reflect the basic theme which is unifying the people. There is one difference between the two speeches which is the length but the content is the same. The concept of the self, Ingroup outgroup relationships and Gemeinschaft and Gesellschaft are used and applied in the two speeches with the same rate nearly.

\section{References}

Alfred Schutz (1972). "Der Fremde". In A. Schutz(ed.),Gesammelte Aufsatze. Band Z. Den Haag: Nijhoff.

Atkinson , Rital, Atkinson ,Richard C. ,Hilgard ,Ernest R (1983). Introduction to Psychology .USA, New York: Harcourt Brace Jovanovich, Inc. $8^{\text {th }}$ Edition.

Baldwin, Elaie Baldwin , Longhurst ,Brain., McCracken ,Scott, Oghorn .Smith, Greg (2004).Introducing Cultural Studies. England: Pearson Education Limited.

Billington, Rosamund, Strawbridge, Sheelagh, Greensides, Leoore, Fitzsimons, Annette( 1991). Culture and Society. Hong Kong: The Macmillan. Press Ltd.

Blum-Kulka ,S., Blondheim, M.,House,J., Kasper,G.and Wagner, J.( 2008) "Intercultural Pragmatics, language and society ", in P.van Sterkenburg (ed)Unity and Diversity of Languages , Amsterdam/ Philadelphia, PA:Benj amins, PP.155.73

Boxer, D.(2002)" Discourse issues in cross - cultural pragmatics", Annual Review of Applied Linguistics.

Brown ,G and Yule, G.(1983) Discourse Analysis . Cambridge: Cambridge University Press.

Bussman H 2006: " Routledge Dictionary of Language and Linguistics." Taylor \& Francis e-Library .

Campbell, K.K and Jamieson (1992) " Deeds done in words: Presidential Rhetoric and Genre of Governance .The University of Chicago, Chicago.

Carroll, John B.(1969)Language and Psychology, In :Hill, Archibald. Linguistics USA: Voice of America Forum lectures. United States Information Service.

Carruthers, Peter( 1996). Language, thought and conscious: An essay in Philosophical psychology . Cambridge: Cambridge University Press. 
Chappell, Martin. Cultural Theory and Language Teaching .In: Chambers, Angella and Baoill, Donall P.O. Intercultural Communication and Language Learning. Dublin .Ireland: The Royal Irish Academy /The Irish Association for Applied Linguistics.1999.PP 81-90.

David F. Ericson, "Presidential Inaugural Addresses and American Political/Culture," Presidential Studies Quarterly 27(1997): 727-744; and Aaron Goldman," The Word Of God: Presidential Inaugural Addresses," America 175 (1996):10-14.

Davis Kingsley. Human Society. Delhi ,India: Surjeet Publications.1995 2nd Edition.

De Fleur, Melvin L , D'Antonio ,William V. ,De Fleur ,Lois B. Society ( 1971): Man In Society .Illinios, USA: Scott, Foresman and Company.

Encyclopaedia of the Linguistic Sciences (2008). English \& Foreign Languages University, Hyderabad \& formerly of Punjabi University, Patiala.

Fairclough, N.(1992) Discourse and Social Change. Cambridge :Polity Press.

Fairclough, N. (1995b) Critical Discourse Analysis: The Critical Study of Language. London: Longman.

Fairclough, N. (2001) "Critical discourse analysis", in McHoul , A. and Rapley, M.(eda), How to Analyze Talk in Institutional Settings. London Continuum,pp.25-41.

Fairclough, N (2003) Analyzing Discourse: Textual Analysis for Social Research. London: Routledge.

Foucault, M.(1972)The Archaeology of knowledge .Trans .S. Smith. London: Tavistook.

Foucault, M.(1977) Discipline and Punish: The British of the Prison. London: Allen Lane.

Gudykunst, William B. (2000). Methodological issues in conducting theory- based cross - cultural research. In: Helen Spencer- Oatey (ed.), Culturally Speaking.Managing Rapport through Talk across culture, 293.315.London: Continuum.

Hall, S. (1992)" The west and the rest", in Hall ,S. and Gieban, B.(eds), Formations Of Modernity. Cambridge :Polity Press/ Open University.

Hsu, Francis L.K.1985: The self in cross-cultural perspective. In Anthony J. Marsella, George Devos, and Francis. L.K.Hus(eds), Culture and Self : Asian and western perspectives, New York: Tavistock Publication.

Jackson. J. (2012). The Routledge Handbook of Language and Intercultural Communication. Routledge 2Park Square, Milton. Abingdon Oxon Ox144 RN

Jones, J. and Peccei, J.S.(2004) 'Language and Politics', in Thomas, L.(ed), Language, Society , and Power. New York: Routledge

Kaplan, Robert B (1986). Culture and Written Language. In: Valdes, Joyce Merril. Culture Bound: Bridging the cultural gap in language teaching. Cambridge: Cambridge University Press

Kasper, G.(1996). "The development of pragmatic Competence", in E.Kelleman, B. Weltens and T. Bongaerts (eds) EUROSLA6: A Selection of papers ,55(2):103-20.

Kasper, G. (1998). " Interlanguage pragmatics ", in H. Bymes (ed.) Learning Foreign and Second Languages Perspectives in Research and Scholarship, New York: The Modern Language Association of America.

Keach, William. Romanticism and Canguye. In: Curran, Stuart. British. Romanticism .Cambridge: Cambridge University Press

Kecskes, I. (2004)'Lexical meaning, conceptual blending ,cultural crossing'. Intercultural Pragmatics, 1(1): 1-26

Kecskes, I .and Zhang ,F.(2009)" Activating ,seeking and creating common ground: a socio-cognitive approach ', Pragmatics and cognition, 17(2):331-5. 
Kecskes, I.(2011)" Intercultural Pragmatics". In D. Archer and P. Grundy (eds) Pragmatics Reader, London: Routledge.

Koole,T. and Thije,J.D.ten (1994) the Construction of Intercultural Discourse: Team Discussion of Educational Advisers, Amsterdam / Atlanta: RODOPI.

Kotthoff, Helga and Oatey Helen Spencer(2007)" Handbook of Intercultural Communication." Hubert \& Co., Gottingen. Germany.

Lakoff, G \& Johnson, M. (2003). ' Metaphor We Live By'. The University of Chicago Press, Chicago, 60637 The University of Chicago Press, Ltd, London

Lee, John R.E (1991). Language and Culture: the linguistic analysis of culture. In Bastion Graham. Ethno methodology and Human Sciences. Cambridge: Cambridge University Press.

Leech Edmund (1982). Culture and Communication: the logic by which symbols are connected. An Introduction to the use of structuralist analysis in social anthropology. Cambridge: Cambridge University Press.

Lyons, J (1977) Semantics Vol.2. Cambridge: Cambridge University Press.

Lyons, J. (1981) Language and linguistics. Cambridge: Cambridge University Press

Morgan, Clifford T., Kinng Richard A, Weisz, John R, Schpler, John.(1986. Introduction to Psychology Singapore: McGraw -Hill Book Co.

Nelson, Katherine 1996. Language in Cognitive Development: Emergence of the Mediated Mind. Cambridge: Cambridge University Press

Papademetre, Leo. and Scarino, Angela(2000). Integrating Culture Learning in the Language Classroom: A multiPerspective Conceptual Journey for Teachers .Melbourne: Language Australia ,Ltd.

Richardson, J. (2007)' Analyzing Newspapers : An Approach from Critical Discourse Analysis'. First Published: Palgrave Macmillan.

Schaffner, C.(1996). ' Editorial: Political Speeches and Discourse Analysis, Current Issues in Language \& Society,' $3,(3)$

Scollon R. and Scollon S.W." Intercultural Communication A Discourse Approach "Blackwell Publishers Ltd.108Cowley Road Oxford Ox 41JF UK.

Smith, Henry Lee Jr (1969): Language and the Total System of Communication, In: Fill, Archibald. Linguistics. USA : Voice of America forum lectures. United States Information service.

Talpot ,M.(2007) Media Discourse: Representation and Interaction. Edinburgh University Press.

Townson, Michael (1999). Culture as Memory. In: Chambers, Angella and Baoill, Donall P.O. Intercultural Communication and Language Learning. Dublin, Ireland:The Royal Irish Academy /The Irish Association For Applied Linguistics.

Valdes, Joyce Merril. (1986) Culture I Literature. In Valdes, Joyce Merril. Culture Bound: Bridging the cultural gap in language teaching. Cambridge: Cambridge University Press

Valdes, Joyce (1990) .The Inevitability of Teaching and Learning Culture in a Foreign Language Course. In: Harrison, Brain. Culture and the Language Classroom. Hong Kong: Modern English Publications and the British Council.

Valette, Rebecca M (1986).The I culture test. In: Valdes, Joyce Merril. Culture Bound: Bridging the cultural gap in language teaching. Cambridge: Cambridge University Press.

Van Dijk (1977) Text and Context: Exploration in the Semantics and_Pragmatics of Discourse. London: Longman. 
Van Dijk, T.A.(1993) Elite Discourse and Racism. Newbury Park, CA: Sage.

Van Dijk, T.A. (ed) (2006), 'Discourse, Interaction and Cognition'. SpeciaL Issue, Discourse Studies.

Vershueren , J.(1999)Understanding Pragmatics. London: Arnold.

Westbrook Eakins, Barbara and R. Gene Eakins 1982: Sex differences in nonverbal communication. In: Larry A. Samovar and Richard E. Porte) (eds), Intercultural Communication: a reader .Belmont, California: Wadsworth Publishing Company.

Wareing, S.(2004)' What is Language and what does it do?' in Thomas, L.(ed), Language Society, and power. New York: Routledge

Wodak, R. (2009). The Discourse of Politics in Action. London: Palgrave Macmillan

Yli-Renko, Kaarina (1993)" Intercultural Communication in Foreign Language Education.

Yule. G.( 1996 b) The Study of Language $2^{\text {nd }}$. Cambridge: Cambridge University Press

Yule, G (1996a) Pragmatics. Oxford: Oxford University Press. 